\title{
New insight into diversity in the genus Xenorhabdus, including the description of ten novel species
}

\author{
Patrick Tailliez, Sylvie Pagès, Nadège Ginibre and Noël Boemare
}

Correspondence

Patrick Tailliez

tailliez@univ-montp2.fr
The genus Xenorhabdus was first described by Thomas \& Poinar (1979). The bacteria of this genus are symbiotically associated with insect-pathogenic nematodes of the genus Steinernema (Travassos, 1927). This genus currently comprises Xenorhabdus nematophila Thomas and Poinar 1979 (the type species), three further species described by Akhurst \& Boemare (1988) (Xenorhabdus beddingii, X. bovienii and X. poinarii), Xenorhabdus japonica described by Nishimura et al. (1994), four species described recently by Lengyel et al. (2005) (Xenorhabdus budapestensis, X. ehlersii, $X$. innexi, $X$. szentirmaii) and 'Xenorhabdus indica',

The GenBank/EMBL/DDBJ accession numbers for the 16S rRNA gene sequences obtained in this study are listed in Table 1. described by Somvanshi et al. (2006) but not yet validly published. Our collection comprised 76 Xenorhabdus strains isolated from at least 27 Steinernema species collected in 32 countries. The strains were characterized by molecular and phenotypic approaches. The phylogenetic spectrum of these Xenorhabdus strains was found to be broad, including many novel species dispersed among type strains in the 16S rRNA gene phylogenetic tree.

\section{Bacterial strains and culture conditions}

The bacterial strains studied were part of our collection (31 strains) (Université Montpellier II, France) or were provided by the DSMZ collection (six strains) (http:// 
www.dsmz.de) (Table 1). Thirty-nine new isolates were obtained from the infective stages of nematodes of the genus Steinernema (Table 1) by the hanging-drop technique (Poinar, 1966). Bacteriological purity was checked by plating on nutrient agar supplemented with $0.004 \%$ $(\mathrm{w} / \mathrm{v})$ triphenyltetrazolium chloride and $0.0025 \%(\mathrm{w} / \mathrm{v})$ bromothymol blue (NBTA medium) at $28{ }^{\circ} \mathrm{C}$ (Akhurst, 1980). The isolates were examined for the main phenotypic characteristics of the genus Xenorhabdus, using the methods of Boemare \& Akhurst (1988). Strains were stored at $-80{ }^{\circ} \mathrm{C}$ in LB broth (Difco) containing $15 \%$ glycerol (v/v).

\section{Phenotypic characterization of bacterial strains and data analysis}

Growth at various temperatures from 32 to $42^{\circ} \mathrm{C}$, enzymic activities on API $20 \mathrm{E}$ and API $20 \mathrm{NE}$ strips (bioMérieux), carbon source assimilation on Biotype 100 (bioMérieux) and fermentation on API $50 \mathrm{CH}$ strips (bioMérieux) were assessed as described by Fischer-Le Saux et al. (1999b). Phenotypic tests on agar plates (ampicillin susceptibility, dye adsorption, colony pigmentation, antibiosis, cultures in Tween media, gelatin hydrolysis, DNase and lecithinase activities, haemolysis) have been described elsewhere (Akhurst, 1980; Boemare \& Akhurst, 1988; Akhurst et al., 1996). Phenotypic data were analysed with BioNumerics software (Applied Maths). Five similarity matrices were calculated using only variable characters, each corresponding to a set of data: growth at different temperatures (11 variable characters), enzyme activities $(n=10)$, carbon source assimilation $(n=69)$, carbon source fermentation $(n=45)$ and phenotypic tests on agar plates $(n=18)$. Weakly positive results were scored as 0.5 and the data were compared using the Gower similarity coefficient (Gower \& Legendre, 1986). The five similarity matrices were combined such that each set of data contributed equally to the combined similarity matrix, regardless of the number of characters it contained. The resulting dendrogram was calculated by the unweighted pair group method using arithmetic means (UPGMA) (Sokal \& Michener, 1958).

\section{Molecular characterization of bacterial strains and data analysis}

Total bacterial genomic DNA was extracted with the QIAamp DNA mini kit (Qiagen). The almost-complete $16 \mathrm{~S}$ rRNA gene was amplified by PCR using primers 16SP1 (5'-GAAGAGTTTGATCATGGCTC-3', corresponding to Escherichia coli 16S rRNA positions 6-25, forward) and 16SP2 (5'-AAGGAGGTGATCCAGCCGCA-3', corresponding to positions $1522-1540$, reverse). PCR was carried out in a final volume of $50 \mu \mathrm{l}$ containing 20-100 ng DNA, $3 \mathrm{mM} \mathrm{MgCl}_{2}$ (Invitrogen), $0 \cdot 1 \mathrm{mM}$ of each primer, $200 \mu \mathrm{M}$ of each dNTP (Invitrogen) and 2.5 U Taq DNA polymerase (Invitrogen) in the buffer supplied with the enzyme. Amplification conditions were: $94^{\circ} \mathrm{C}$ for $2 \mathrm{~min}$ followed by 35 cycles of 30 s at $95^{\circ} \mathrm{C}, 30 \mathrm{~s}$ at $63^{\circ} \mathrm{C}$ and 1 min at $72^{\circ} \mathrm{C}$, followed by $7 \mathrm{~min}$ at $72^{\circ} \mathrm{C}$. PCR products were purified using a Montage PCR device (Millipore). Sequences overlapping the $16 \mathrm{~S}$ rRNA gene were then obtained using three sequencing primers (SP1, 5'-ACCGCGGCTGCTGGCACG-3', position 514 reverse; SP2, 5'-CTCGTTGCGGGACTTAAC-3', position 1089 reverse; and 16SP2) and merged using SeqMan II (DNAStar). Multiple alignments of the 16S rRNA gene sequences were obtained with CLUSTAL $\mathrm{W}$ (http://clustalw.genome.jp/) and the distance tree was calculated using the model of Jukes \& Cantor (1969) and the neighbour-joining (NJ) method (Saitou \& Nei, 1987) included in PAUP software (Swofford, 2003). Bootstrap analysis was carried out with 1000 datasets. We also used the maximum-likelihood (ML) and parsimony methods included in PAUP to compare the topologies of the phylogenetic trees obtained for a given set of sequences.

The 16S rRNA gene restriction fragment length polymorphism (RFLP) typing method was carried out as described previously (Fischer-Le Saux et al., 1998). The RFLP data are not presented here, but were used to select representative strains of $X$. bovienii (11/25), X. nematophila (6/13) and X. poinarii (4/5) from the strains of our collection for which $16 \mathrm{~S}$ rRNA gene sequences have been determined. Randomly amplified polymorphic DNA (RAPD) profiles (Williams et al., 1990) were determined using primers $\mathrm{P} 1{ }^{\prime} 5^{\prime}$ TGCTCTGCCC-3'), P2 (5'-GGTGACGCAG- $\left.3^{\prime}\right)$ and P3 $\left(5^{\prime}\right.$-TCGCTGGGAC- $\left.3^{\prime}\right)$ in separate reactions. Enterobacterial repetitive intergenic consensus (ERIC) (Hulton et al., 1991) PCR profiles were determined using the primers ERIC1R (5'-GCTATGCTCCYGGGGRTT- $3^{\prime}$ ) and ERIC2 $\left(5^{\prime}\right.$-ACTATGTGAYTGGGGTGA- $\left.3^{\prime}\right)$. The sequences of the ERIC primers proposed by Versalovic et al. (1991) were modified to correspond to the ERIC sequences present in the Xenorhabdus genome (http://maizeapache.ddpsc.org/ xeno_blast/index.html). PCR amplifications were performed in a final volume of $50 \mu \mathrm{l}$ containing $1 \times$ PCR buffer (Qbiogene), 20-100 ng bacterial genomic DNA, $0 \cdot 2 \mathrm{mM} \mathrm{MgCl}_{2}, 0 \cdot 5 \mu \mathrm{M}$ primer, $200 \mu \mathrm{M}$ of each dNTP and 3.75 U Taq DNA polymerase (concentration of enzyme

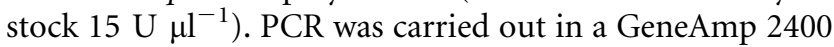
thermal cycler PCR system (Perkin Elmer) programmed for 30 cycles of amplification of $1 \mathrm{~min}$ at $94^{\circ} \mathrm{C}, 1 \mathrm{~min}$ at $48^{\circ} \mathrm{C}$ (ERIC) or $42^{\circ} \mathrm{C}$ (RAPD), $3 \mathrm{~min}$ (ERIC) to $6 \mathrm{~min}$ (RAPD) of temperature ramping to $72{ }^{\circ} \mathrm{C}$ and $1 \mathrm{~min}$ at $72^{\circ} \mathrm{C}$, after an initial $5 \mathrm{~min}$ denaturation at $94^{\circ} \mathrm{C}$. Electrophoresis was carried out as described previously (Tailliez et al., 1998). Molecular typing profiles were acquired with a CCD camera (Sony) and photocapture software (PHOTO-CAPT; Fisher Bioblock Scientific). For each strain, the ERIC profile and the three RAPD profiles were combined and then compared using Pearson's similarity coefficient. The resulting dendrogram was calculated with the UPGMA module of the GelCompar software (Applied-Maths).

\section{Comparison of 16S rRNA gene sequences}

Fig. 1 shows the distance tree resulting from comparison of the 16S rRNA gene sequences of 54 representative Xenorhabdus strains selected from the 76 strains studied (Table 1). Representative strains were selected from the 
Table 1. Xenorhabdus strains and isolates included in this study

Type strains and proposed type strains are highlighted in bold.

\begin{tabular}{|c|c|c|c|c|c|c|c|c|}
\hline Strain & $\begin{array}{l}\text { Previously } \\
\text { classified as: }\end{array}$ & $\begin{array}{c}\text { Proposed } \\
\text { classification }\end{array}$ & $\begin{array}{c}\text { 16S rRNA gene } \\
\text { GenBank accession no. }\end{array}$ & Group & $\begin{array}{l}\text { Steinernema } \\
\text { host species }\end{array}$ & $\begin{array}{l}\text { Geographical } \\
\text { origin }\end{array}$ & Source & Reference $(s)^{\star}$ \\
\hline \multicolumn{9}{|c|}{ Strains assigned to recognized species } \\
\hline $\mathrm{Q}^{\mathrm{T} 8^{\mathrm{T}}}$ & $X$. beddingii & X. beddingii & AY278675 & & Unknown & Australia & R. Akhurst & $2,3,4,5,6,11$ \\
\hline $\mathrm{T} 228^{\mathrm{T}}$ & X. bovienii & X. bovienii & X82252 & $\mathrm{G}_{8}$ & S. feltiae & Australia & R. Akhurst & $1,4,5,6$ \\
\hline Dan & X. bovienii & $X$. bovienii & & $\mathrm{G}_{8}$ & S. affine & Denmark & R. Akhurst & 3 \\
\hline F3 & X. bovienii & $X$. bovienii & DQ202311 & $\mathrm{G}_{8}$ & S. affine & France & E. Bonifassi & $3,4,5,6$ \\
\hline F5 & X. bovienii & $X$. bovienii & & $\mathrm{G}_{8}$ & S. feltiae & France & E. Bonifassi & $3,5,6$ \\
\hline F7 & X. bovienii & $X$. bovienii & & $\mathrm{G}_{8}$ & S. feltiae & France & E. Bonifassi & 3 \\
\hline FR10 & X. bovienii & $X$. bovienii & AY521240 & $\mathrm{G}_{8}$ & S. feltiae & France & E. Bonifassi & 11 \\
\hline N60 & X. bovienii & $X$. bovienii & & $\mathrm{G}_{8}$ & S. feltiae & Australia & R. Akhurst & 3 \\
\hline $\mathrm{Si}$ & $X$. bovienii & $X$. bovienii & DQ205455 & $\mathrm{G}_{8}$ & S. intermedium & USA & R. Akhurst & $4,5,6$ \\
\hline SK2 & X. bovienii & $X$. bovienii & & $\mathrm{G}_{8}$ & S. kraussei & Czech Republic & R. Akhurst & $3,4,5,6$ \\
\hline BE04 & & $X$. bovienii & & $\mathrm{G}_{8}$ & S. affine & Belgium & M. Moens & This work \\
\hline BE05 & & $X$. bovienii & & $\mathrm{G}_{8}$ & S. affine & Belgium & M. Moens & This work \\
\hline CA04 & & $X$. bovienii & DQ205454 & $\mathrm{G}_{8}$ & S. kraussei & Canada & G. Bélair & This work \\
\hline $\mathrm{CS} 03$ & & $X$. bovienii & DQ205452 & $\mathrm{G}_{8}$ & S. weiseri & Czech Republic & Z. Mráček & This work \\
\hline CS66 & & $X$. bovienii & DQ205451 & $\mathrm{G}_{8}$ & S. kraussei & Czech Republic & Z. Mráček & This work \\
\hline FR11 & & X. bovienii & & $\mathrm{G}_{8}$ & S. feltiae & France & E. Bonifassi & This work \\
\hline FR12 & & X. bovienii & & $\mathrm{G}_{8}$ & S. feltiae & France & E. Bonifassi & This work \\
\hline USCA99 & & $X$. bovienii & & $\mathrm{G}_{8}$ & S. feltiae & USA & P. Stock & This work \\
\hline SN1 & & X. bovienii & & $\mathrm{G}_{8}$ & S. feltiae & France & P. Stock & This work \\
\hline ТВ01 & & $X$. bovienii & & $\mathrm{G}_{8}$ & Not yet defined & China & Z. Mráček & This work \\
\hline TB10 & & X. bovienii & DQ208304 & $\mathrm{G}_{8}$ & Not yet defined & China & Z. Mráček & This work \\
\hline TB20 & & Xenorhabdus sp. & DQ208305 & $\mathrm{G}_{8}$ & Not yet defined & China & Z. Mráček & This work \\
\hline TB30 & & $X$. bovienii & DQ208306 & $\mathrm{G}_{8}$ & Not yet defined & China & Z. Mráček & This work \\
\hline TR15 & & $X$. bovienii & & $\mathrm{G}_{8}$ & S. feltiae & Turkey & P. Stock & This work \\
\hline USFL53 & & $X$. bovienii & & $\mathrm{G}_{8}$ & S. feltiae & USA & G. Smart & This work \\
\hline USNY95 & & X. bovienii & DQ205453 & $\mathrm{G}_{8}$ & S. kraussei & USA & P. Stock & This work \\
\hline DSM $16342^{T}$ & X. budapestensis & X. budapestensis & AJ810293 & $\mathrm{G}_{2}$ & S. bicornutum & Serbia & DSMZ & 8 \\
\hline $\mathrm{CN} 03$ & & X. budapestensis & DQ211714 & $\mathrm{G}_{2}$ & S. ceratophorum & China & P. Stock & This work \\
\hline DSM $16337^{\mathrm{T}}$ & X. ehlersii & X. ehlersii & AJ810294 & $\mathrm{G}_{1}$ & S. serratum $\dagger$ & China & DSMZ & 8 \\
\hline CN01 & & $X$. ehlersii & DQ208307 & $\mathrm{G}_{1}$ & S. serratum $\dagger$ & China & J. Liu & 6 \\
\hline KR02 & & $X$. ehlersii & DQ208308 & $\mathrm{G}_{1}$ & S. longicaudum & Korea & H. Choo & This work \\
\hline KR03 & & X. ehlersii & DQ202306 & $\mathrm{G}_{1}$ & Unknown & Korea & H. Choo & This work \\
\hline USCA98 & & X. ehlersii & DQ202312 & $\mathrm{G}_{1}$ & S. longicaudum & USA & P. Stock & This work \\
\hline DSM 17382 & 'X. indica' & ' $X$. indica' & AM040494 & $\mathrm{G}_{5}$ & S. thermophilum & India & DSMZ & 12 \\
\hline OM01 & & ' $X$. indica' & DQ211718 & $\mathrm{G}_{5}$ & S. abbasi & Sultanate of Oman & S. Elawad & This work \\
\hline
\end{tabular}


Table 1. cont.

\begin{tabular}{|c|c|c|c|c|c|c|c|c|}
\hline Strain & $\begin{array}{l}\text { Previously } \\
\text { classified as: }\end{array}$ & $\begin{array}{c}\text { Proposed } \\
\text { classification }\end{array}$ & $\begin{array}{c}\text { 16S rRNA gene } \\
\text { GenBank accession no. }\end{array}$ & Group & $\begin{array}{l}\text { Steinernema } \\
\text { host species }\end{array}$ & $\begin{array}{l}\text { Geographical } \\
\text { origin }\end{array}$ & Source & Reference $(s)^{*}$ \\
\hline DSM $16336^{T}$ & $X$. innexi & $X$. innexi & AJ810292 & $\mathrm{G}_{3}$ & S. scapterisci & Uruguay & DSMZ & 8 \\
\hline UY61 & & $X$. innexi & AY521243 & $\mathrm{G}_{3}$ & S. scapterisci & Uruguay & G. Smart & 6,11 \\
\hline DSM $16522^{T}$ & X. japonica & X. japonica & DQ202310 & $\mathrm{G}_{6}$ & S. kushidai & Japan & DSMZ & 9 \\
\hline $\mathrm{AN6}^{\mathrm{T}}+$ & X. nematophila & X. nematophila & AY278674 & $\mathrm{G}_{10}$ & S. carpocapsae & USA & R. Akhurst & $4,5,6,11$ \\
\hline A24 & X. nematophila & X. nematophila & & $\mathrm{G}_{10}$ & S. carpocapsae & Russia & R. Akhurst & $1,3,4,5,6$ \\
\hline DD136 & X. nematophila & X. nematophila & & $\mathrm{G}_{10}$ & S. carpocapsae & USA & C. Laumond & 10 \\
\hline F1 & X. nematophila & X. nematophila & AY521241 & $\mathrm{G}_{10}$ & S. carpocapsae & France & E. Bonifassi & $3,4,5,6,11$ \\
\hline NC116 & X. nematophila & $X$. nematophila & & $\mathrm{G}_{10}$ & S. carpocapsae & USA & R. Akhurst & 3 \\
\hline PL31 & X. nematophila & $X$. nematophila & AY521242 & $\mathrm{G}_{10}$ & S. carpocapsae & Poland & J. Jarosz & 11 \\
\hline A 20 & & X. nematophila & & $\mathrm{G}_{10}$ & S. carpocapsae & Portugal & N. Simões & This work \\
\hline BE06 & & X. nematophila & DQ211704 & $\mathrm{G}_{10}$ & S. carpocapsae & Belgium & M. Moens & This work \\
\hline CA01 & & X. nematophila & DQ211705 & $\mathrm{G}_{10}$ & S. carpocapsae & Canada & G. Bélair & This work \\
\hline CBY & & X. nematophila & & $\mathrm{G}_{10}$ & S. carpocapsae & China & R. Akhurst & This work \\
\hline ES96 & & X. nematophila & DQ211707 & $\mathrm{G}_{10}$ & S. carpocapsae & Spain & R. Campos Herrera & This work \\
\hline USCA97 & & X. nematophila & & $\mathrm{G}_{10}$ & S. carpocapsae & USA & G. Poinar & This work \\
\hline MX102 & & X. nematophila & & $\mathrm{G}_{10}$ & S. carpocapsae & Mexico & G. Poinar & This work \\
\hline $\mathrm{G}^{\mathrm{T}}$ & $X$. poinarii & $X$. poinarii & D78010 & $\mathrm{G}_{9}$ & S. glaseri & USA & R. Akhurst & $4,5,6,7,11$ \\
\hline CU01 & $X$. poinarii & $X$. poinarii & DQ211706 & $\mathrm{G}_{9}$ & S. cubanum & Cuba & E. Arteaga & 7 \\
\hline NC33 & $X$. poinarii & $X$. poinarii & & $\mathrm{G}_{9}$ & S. glaseri & USA & R. Akhurst & $3,5,6,7$ \\
\hline SK72 & $X$. poinarii & $X$. poinarii & AY521239 & $\mathrm{G}_{9}$ & S. glaseri & USA & N. Simões & $6,7,11$ \\
\hline AZ26 & & $X$. poinarii & DQ211703 & $\mathrm{G}_{9}$ & S. glaseri & Portugal & N. Simões & This work \\
\hline DSM $16338^{T}$ & X. szentirmaii & X. szentirmaii & AJ810295 & $\mathrm{G}_{12}$ & S. rarum & Argentina & DSMZ & 8 \\
\hline AR81 & & X. szentirmaii & DQ211708 & $\mathrm{G}_{12}$ & S. rarum & Argentina & P. Stock & This work \\
\hline K77 & & X. szentirmaii & DQ211712 & $\mathrm{G}_{12}$ & S. rarum & Argentina & M. Doucet & $4,5,6$ \\
\hline \multicolumn{9}{|c|}{ Strains assigned to novel species } \\
\hline $\mathrm{KE}^{\mathrm{T}}{ }^{\mathrm{T}}$ & & X. hominickii & DQ211719 & $\mathrm{G}_{7}$ & S. karii & Kenya & P. Stock & This work \\
\hline KR01 & & X. hominickii & DQ205448 & $\mathrm{G}_{7}$ & S. monticolum & Korea & P. Stock & 6 \\
\hline KR05 & & X. hominickii & DQ205449 & $\mathrm{G}_{7}$ & S. monticolum & Korea & P. Stock & This work \\
\hline $\mathrm{SaV}^{\mathrm{T}}$ & & X. kozodoii & DQ211716 & $\mathrm{G}_{4}$ & S. arenarium & Russia & R. Akhurst & $4,5,6$ \\
\hline ES01 & & X. kozodoii & DQ202308 & $\mathrm{G}_{4}$ & Not yet defined & Spain & O. Triggiani & This work \\
\hline IT10 & & X. kozodoii & DQ202308 & $\mathrm{G}_{4}$ & S. apuliae & Italia & O. Triggiani & This work \\
\hline FRM16 $^{\mathrm{T}}$ & & $X$. doucetiae & DQ211709 & $\mathrm{G}_{11}$ & S. diaprepesi & Martinique & H. Mauléon & 6 \\
\hline FRG30 & & $X$. doucetiae & DQ211702 & $\mathrm{G}_{11}$ & S. diaprepesi & Guadeloupe & H. Mauléon & This work \\
\hline $\mathrm{USTX}^{\mathrm{T}}{ }^{\mathrm{T}}$ & & X. cabanillasii & AY521244 & $\mathrm{G}_{13}$ & S. riobrave & USA & E. Cabanillas & 6,11 \\
\hline JM26 & & X. cabanillasii & DQ211711 & $\mathrm{G}_{13}$ & S. riobrave & Jamaica & H. Mauléon & 6 \\
\hline ID10 $^{\mathrm{T}}$ & & X. griffiniae & DQ211710 & & S. hermaphroditum & Indonesia & C. Griffin & This work \\
\hline PR06-A $^{T}$ & & $X$. romanii & DQ211717 & & S. puertoricense & Puerto Rico & H. Mauléon & 6 \\
\hline $\mathrm{Q} 1^{\mathrm{T}}$ & & X. miraniensis & DQ211713 & & Steinernematidae & Australia & R. Akhurst & 4 \\
\hline $\mathrm{THO1}^{\mathrm{T}}$ & & X. stockiae & DQ202309 & & S. siamkayai & Thailand & P. Stock & This work \\
\hline
\end{tabular}




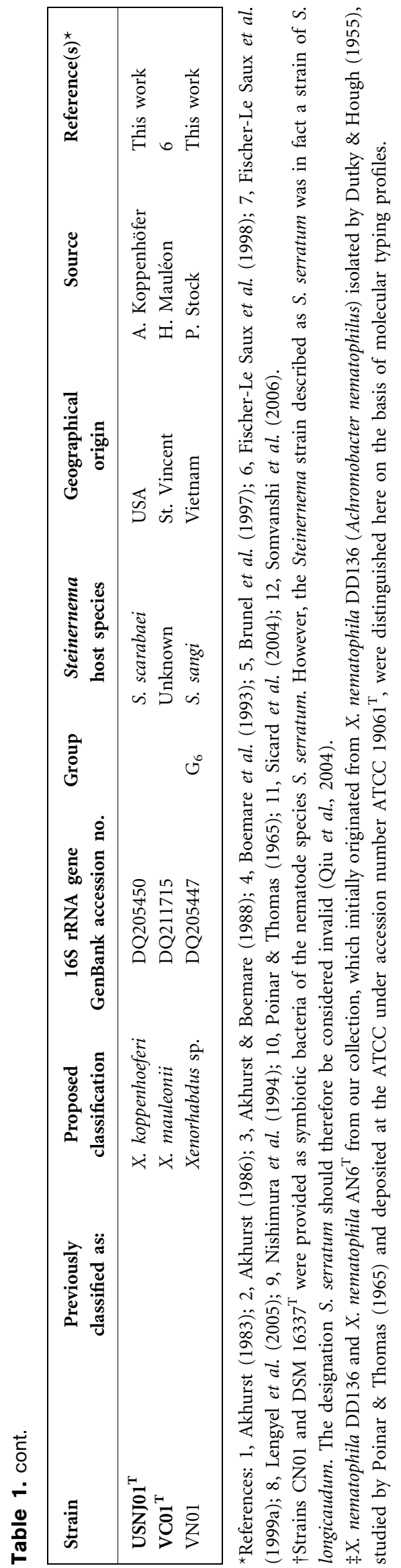

species $X$. nematophila, X. bovienii and X. poinarii, taking into account geographical origin, species of nematode host and the diversity of 16S rRNA gene RFLP profiles. The 16S rRNA gene sequence obtained from strain IAM $14265^{\mathrm{T}}$, which should correspond to $X$. japonica SK- $1^{\mathrm{T}}$, was actually similar to that of $X$. nematophila strains and therefore significantly different from the sequence of $X$. japonica SK- $1^{\mathrm{T}}$ deposited in GenBank under accession number D78008. Our result was confirmed by the staff of the IAM collection. We therefore used the $X$. japonica type strain deposited in the DSMZ under accession number DSM $16522^{\mathrm{T}}$ instead. This strain has a $16 \mathrm{~S}$ rRNA gene sequence (GenBank accession number DQ202310) very similar to the GenBank sequence of $X$. japonica SK-1 ${ }^{\mathrm{T}}$.

The 16S rRNA gene sequences of the Xenorhabdus strains studied here displayed more than $95 \%$ similarity. If we consider a mean substitution rate for the 16S rRNA in eubacteria of about $1-2 \%$ per 50 million years (Ochman \& Wilson, 1987; Moran et al., 1993), the common ancestor of the genus Xenorhabdus probably emerged between 250 and 500 million years ago. These data are consistent with Poinar's speculations that nematodes of the genus Steinernema probably emerged about 375 million years ago (Poinar, 1993). On the bacterial evolution time scale, we can consider the genus Xenorhabdus to have emerged relatively recently.

Forty-seven sequences were distributed between 13 groups, $G_{1}$ to $G_{13}$, based on high bootstrap values (>98\%) in the distance tree. Seven sequences, corresponding to strains $\mathrm{TH}_{01}{ }^{\mathrm{T}}, \mathrm{ID} 10^{\mathrm{T}}, \mathrm{USNJ}^{\mathrm{T}} 1^{\mathrm{T}}, \mathrm{VCO}^{\mathrm{T}}, \mathrm{Q}^{\mathrm{T}}, \mathrm{PR} 06-\mathrm{A}^{\mathrm{T}}$ and $X$. beddingii DSM $4764^{\mathrm{T}}$, were not included in these groups. The composition of the 13 groups of sequences was confirmed using the ML and parsimony methods of phylogenetic tree reconstruction and using the 16S rRNA gene sequences of Photorhabdus luminescens subsp. laumondii $\mathrm{TT}_{0} 1^{\mathrm{T}}$ (GenBank accession no. AJ007404), Proteus vulgaris CIP $103181^{\mathrm{T}}$ (AJ301683) and E. coli ATCC $11775^{\mathrm{T}}$ (X80725) as outgroups (data not shown). Although the bootstrap values at the nodes between groups $G_{1}$ to $G_{4}$ were less than $50 \%$, these four groups were linked similarly by the ML and parsimony methods, suggesting that they were phylogenetically related. Similarly, the sequence of strain ID $10^{\mathrm{T}}$ was linked to those of group $\mathrm{G}_{5}$ and the sequence of strain PR06- $\mathrm{A}^{\mathrm{T}}$ was linked to those of group $\mathrm{G}_{11}$ in all three methods of phylogenetic tree reconstruction. The sequences of strains $\mathrm{TH}_{01} 1^{\mathrm{T}}, \mathrm{USNJ}_{01} 1^{\mathrm{T}}, \mathrm{VCO}^{\mathrm{T}}$ and $\mathrm{Q1}^{\mathrm{T}}$ and the $X$. beddingii type strain DSM $4764^{\mathrm{T}}$ were not robustly linked to any of the 13 groups of sequences defined in this work. Moreover, relationships between the groups, with the exception of relationships between $G_{1}, G_{2}, G_{3}$ and $G_{4}$ (see above), appeared to be unreliable, suggesting (i) that the $16 \mathrm{~S}$ rRNA gene sequences used were insufficiently informative for phylogenetic analysis and/or (ii) an explosive radiation of diversity within the genus Xenorhabdus.

\section{Comparison of molecular typing profiles}

The differences between two Xenorhabdus 16S rRNA gene sequences were often less than $3 \%$ (and always less than 


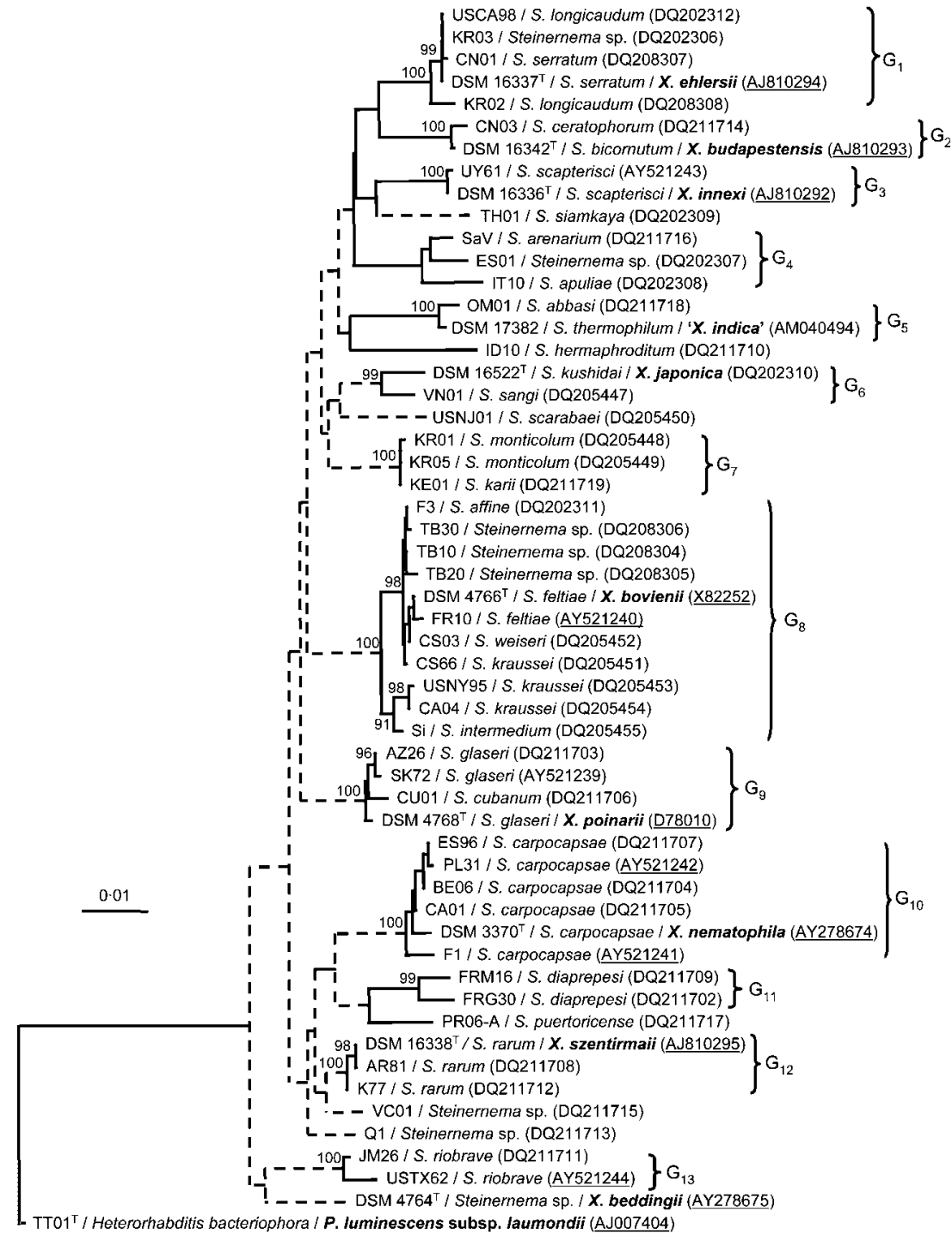

Fig. 1. Distance tree showing the phylogenetic relationships of 54 Xenorhabdus strains and isolates. The tree was constructed using 16S rRNA gene sequences (1433 nucleotides), the model of Jukes \& Cantor (1969) and the neighbour-joining module of PAUP software. Photorhabdus luminescens subsp. laumondii $\mathrm{TTO}^{\top}$ was used as an outgroup. Bootstrap values (percentages of 1000 replicates) of more than $90 \%$ are shown at nodes. Dashed lines indicate unreliable links between groups and unique sequences that were not confirmed by the ML and parsimony methods of phylogenetic tree reconstruction. The underlined accession numbers in parentheses correspond to 16S rRNA gene sequences retrieved from GenBank; the other sequences were determined in this study. Thirteen groups, $G_{1}$ to $G_{13}$, supported by high bootstrap values (>98\%), were identified. Sequences corresponding to type strains are highlighted in bold. When known, the Steinernema species of the corresponding nematode host is indicated. Bar, $1 \%$ sequence divergence.
$5 \%$ ), so this frequently used bacterial taxonomy threshold (Stackebrandt \& Goebel, 1994) cannot be used here to support proposals for novel species of Xenorhabdus. This observation was also true for the genus Photorhabdus of nematode-symbiotic bacteria (Akhurst et al., 2004). Quantitative DNA-DNA hybridization data were available only for representative strains of five species with validly published names, $X$. nematophila, $X$. bovienii, $X$. poinarii, $X$. beddingii and X. japonica (Boemare et al., 1993; Nishimura et al., 1994), and for strains $\mathrm{K} 77, \mathrm{SaV}^{\mathrm{T}}$ and $\mathrm{Q} 1^{\mathrm{T}}$ (Boemare et al., 1993). We therefore assessed the relationships between our strains using a combination of molecular typing techniques (ERIC and RAPD fingerprinting) that could be performed easily for such a large collection of bacteria. These molecular typing methods are based on the amplification of conserved and variable regions of the genome. They enabled us to group together strains belonging to the same species based on the amplification of conserved genomic regions (migration of bands of the same size in different profiles). This approach was used successfully for Campylobacter and its relatives (Mazurier et al., 1992), for which phenotypic inertness has prevented the development of a phenotypic identification scheme (Vandamme et al., 1996), and for some closely related species of lactobacilli showing an overall phenotypic similarity (e.g. the Lactobacillus acidophilus group) (Gancheva et al., 1999). Similarly, the combined use of RAPD and ERIC fingerprinting was used successfully to differentiate Salmonella species (Lim et al., 2005).

A comparison of the molecular typing profiles of the 76 Xenorhabdus strains studied (Fig. 2) led to the identification of groups corresponding to those defined by $16 \mathrm{~S}$ rRNA gene sequences analysis, except for group $G_{6}$, in which strain VN01 and X. japonica DSM $16522^{\mathrm{T}}$ displayed very different molecular typing profiles (Pearson similarity coefficient of $10 \%$ ), and for group $G_{8}$, in which strain TB20 displayed a unique molecular typing profile. Within group $\mathrm{G}_{8}$, strains TB01, TB10 and TB30, all of which originated from China, clustered together and strains CA04 and USNY95, both isolated from Steinernema kraussei, and strain $\mathrm{Si}$, isolated from Steinernema intermedium, were distinguished on the basis of their molecular typing profiles. In addition, the 
DNA-DNA relatedness between $X$. bovienii $\mathrm{T}_{22} 8^{\mathrm{T}}$ (associated with Steinernema feltiae) and strain Si (associated with $S$. intermedium) was only $64 \%$, whereas the DNA relatedness between the $X$. bovienii type strain $\mathrm{T} 228^{\mathrm{T}}$ and strains F3 and SK2 (associated with Steinernema affine and S. kraussei, respectively) was $75 \%$ (Boemare et al., 1993). Within group $\mathrm{G}_{9}, X$. poinarii strain CU01, isolated from Steinernema cubanum, was distinguished from the four $X$. poinarii strains isolated from Steinernema glaseri. Similarly, the DNA-DNA relatedness between $X$. poinarii $\mathrm{G}^{\mathrm{T}}$ (associated with $S$. glaseri) and strain CU01 (associated with $S$. cubanum) was only $68 \%$, with a $\Delta T_{\mathrm{m}}$ value of $3{ }^{\circ} \mathrm{C}$, whereas the DNA-DNA relatedness between X. poinarii $\mathrm{G}^{\mathrm{T}}$ and strain NC33 (associated with S. glaseri) was $96 \%$, with a $\Delta T_{\mathrm{m}}$ value of $2 \cdot 4^{\circ} \mathrm{C}$ (Fischer-Le Saux et al., 1999a). These results obtained using the DNA-DNA hybridization technique and our molecular typing method indicated the particular position of strains Si and CU01 within X. bovienii and $X$. poinarii, respectively. Strains $\mathrm{TH} 01^{\mathrm{T}}, \mathrm{ID} 10^{\mathrm{T}}, \mathrm{VCO}^{\mathrm{T}}$, PR06-A ${ }^{\mathrm{T}}, \mathrm{USNJ} 01^{\mathrm{T}}, \mathrm{Q}^{\mathrm{T}}$ and X. beddingii DSM $4764^{\mathrm{T}}$, the $16 \mathrm{~S}$ rRNA gene sequences of which were not included in any group, displayed unique molecular typing profiles.

Considering a Pearson similarity coefficient threshold above around $40 \%$ to allow reliable assignment of a strain to a given group, the classification of our strains based on molecular typing profile analysis was consistent with that based on DNA-DNA hybridizations performed on representative strains of $X$. beddingii, $X$. bovienii, $X$. japonica, $X$. nematophila and X. poinarii and strains $\mathrm{K} 77, \mathrm{SaV}^{\mathrm{T}}$ and $\mathrm{Q} 1^{\mathrm{T}}$ (Boemare et al., 1993; Fischer-Le Saux et al., 1999a; Nishimura et al., 1994), thus indicating that our molecular typing technique has a level of resolution comparable to that of DNA-DNA hybridization. In addition, the groupings substantiate those obtained from analysis of $16 \mathrm{~S}$ rRNA gene sequences. These results suggest that our approach is a reliable alternative to the quantitative DNA-DNA hybridization method generally used in bacterial taxonomy in cases in which a large number of bacterial strains with very similar 16S rRNA gene sequences are studied. Based on this approach, we were able (i) to classify 32 new isolates to the previously described Xenorhabdus species, adding new members to recently described species previously represented by the type strain only (Lengyel et al., 2005; Somvanshi et al., 2006), (ii) to confirm the validity of the five species proposed by Lengyel et al. (2005) and Somvanshi et al. (2006), despite the absence of quantitative DNA-DNA hybridization data and the high level of similarity of their $16 \mathrm{~S}$ rRNA gene sequences (e.g. X. budapestensis-X. ehlersii, $98 \%$; X. szentirmaii-X. nematophila, $97 \cdot 5 \%$ ), (iii) to propose the description of ten novel Xenorhabdus species (see below) and (iv) to assign 16 strains to these novel Xenorhabdus species, with isolates VN01 and TB20 remaining unclassified.

\section{Comparison of phenotypic patterns}

All the strains displayed the phenotypic characters of form I described previously for the genus Xenorhabdus (Akhurst \& Boemare, 2005) with the exception of X. ehlersii DSM
$16337^{\mathrm{T}}$ and $X$. japonica DSM $16522^{\mathrm{T}}$, provided by the DSMZ, which contained form II only. All strains except $X$. bovienii BE05, X. ehlersii DSM $16337^{\mathrm{T}}$ and X. japonica DSM $16522^{\mathrm{T}}$ produced antibiotics and none of the strains displayed any of the following characters: bioluminescence, oxidase, catalase, urease or nitrate reductase activity, VogesProskauer reaction, ONPG (o-nitrophenol $\beta$-D-galactopyranoside) and $\mathrm{H}_{2} \mathrm{~S}$ production. Table 2 summarizes the most significant phenotypic features of the strains of the previously described Xenorhabdus species and of the ten novel Xenorhabdus species proposed here.

We compared the phenotypic patterns of the 76 strains studied here (Fig. 3). Similarity coefficients exceeded $70 \%$, suggesting that phenotypic analysis would be unlikely to lead to the identification of phenotypic features for reliable discrimination between Xenorhabdus species. A comparison of the phenotypic patterns led to the identification of two main phenotypic groups. Phenotypic group $\mathrm{G}_{\mathrm{A}}$ comprised strains able to grow at temperatures of $35-42{ }^{\circ} \mathrm{C}$, whereas phenotypic group $\mathrm{G}_{\mathrm{B}}$ comprised strains growing at temperatures below $35^{\circ} \mathrm{C}$, suggesting that some Xenorhabdus species may have become adapted to tropical or temperate regions and/or influenced by the optimal growth and development temperature of their nematode host [e.g. the optimum temperatures for growth and development of Steinernema carpocapsae, S. monticolum, S. scarabaei and S. weiseri, associated with $X$. nematophila, Xenorhabdus hominickii sp. nov., Xenorhabdus koppenhoeferi sp. nov. and $X$. bovienii (group $\mathrm{G}_{\mathrm{B}}$ ), respectively, ranged from 20 to $25^{\circ} \mathrm{C}$, whereas those of Steinernema riobrave and S. abbasi, associated with Xenorhabdus cabanillasii sp. nov. and ' $X$. indica' (group $\mathrm{G}_{\mathrm{A}}$ ), respectively, ranged from 30 to $35^{\circ} \mathrm{C}$ (Cabanillas et al., 1994; Elawad et al., 1997; Mráček et al., 2003; Saunders \& Webster, 1999; Stock \& Koppenhöfer, 2003; Stock et al., 1997)]. The reliable phylogenetic relationships between strains of groups $G_{1}$ to $G_{4}$ (Fig. 1) were supported by the ability of the corresponding strains to grow at temperatures above $35^{\circ} \mathrm{C}$. Similarly, the phylogenetic relationships identified between strains $I D 10^{\mathrm{T}}$ and the ' $X$. indica' strains (group $G_{5}$ ) and between strain PR06- ${ }^{\mathrm{T}}$ and strains FRM16 ${ }^{\mathrm{T}}$ and FRG31 (Xenorhabdus doucetiae sp. nov., group $\mathrm{G}_{11}$ ) were supported by the ability of these strains to grow at temperatures above $35^{\circ} \mathrm{C}$.

In the examples cited below, the classification of phenotypic patterns (Fig. 3) was generally consistent with the molecular classifications presented in Figs 1 and 2. The phenotypic patterns of the $X$. nematophila strains clustered together except for $X$. nematophila strain BE06, which was clustered with X. japonica DSM $16522^{\mathrm{T}}$ (phase II). The X. nematophila strains were characterized by an ability to grow only at temperatures below $35^{\circ} \mathrm{C}$, to produce acid from trehalose and to assimilate fructose and an inability to assimilate D-gluconate. Colonies were not pigmented. The phenotypic patterns of the X. bovienii strains also clustered together except for strains CA04 and USNY95. Similarly, strain TB20 displayed a unique phenotypic pattern. The $X$. bovienii 


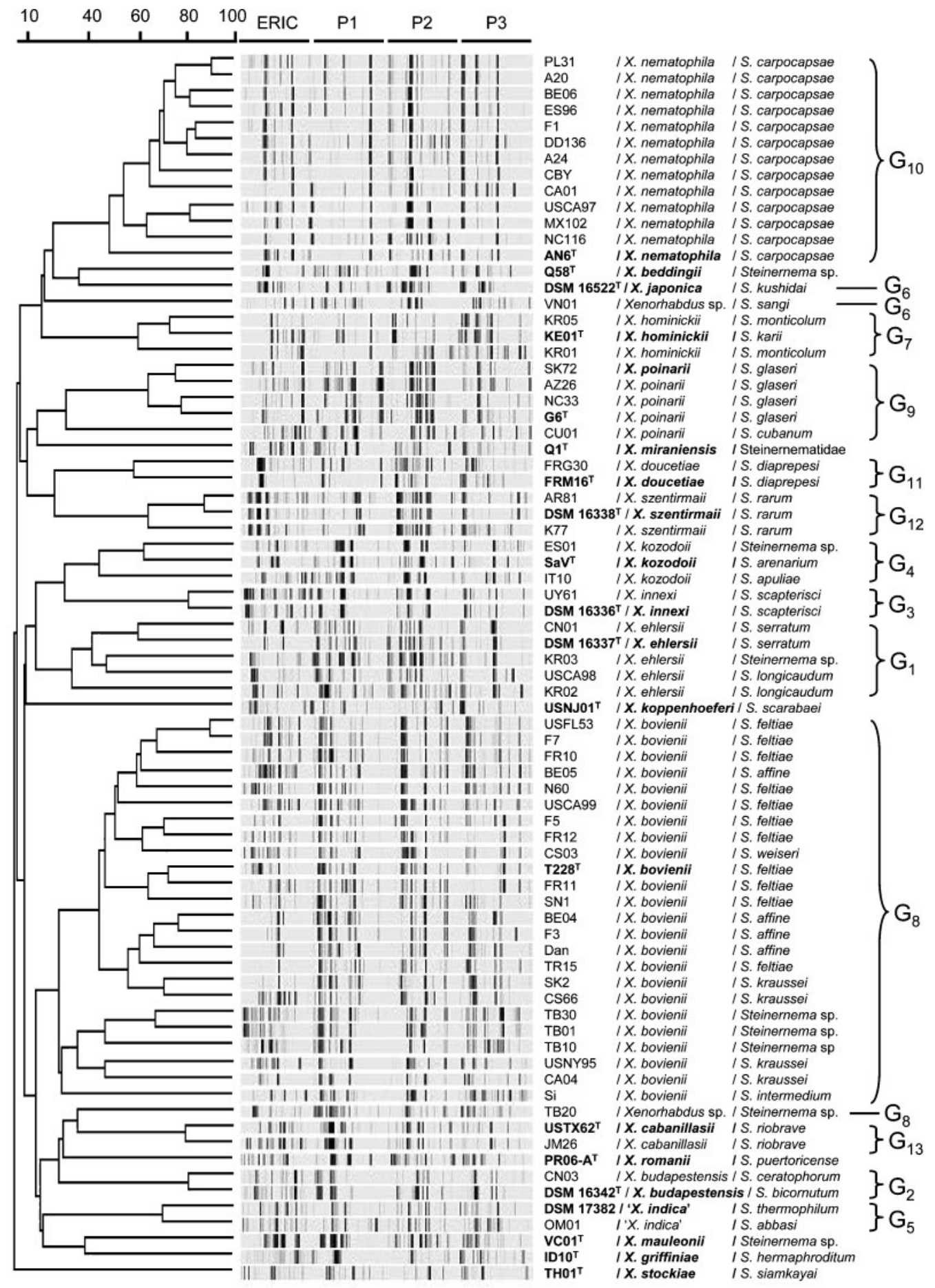

Fig. 2. Comparison of the molecular typing profiles of the 76 Xenorhabdus strains and isolates studied. One ERIC profile and three RAPD profiles obtained with the primers P1, P2 and P3, used in independent reactions, were combined for each strain. The combined molecular typing profiles were compared using Pearson's similarity coefficient. The corresponding similarity matrix was used to generate a dendrogram using the UPGMA module of the GelCompar software (Applied Maths). Type strains are highlighted in bold. Molecular profiles were established for strains $\mathrm{G}^{\top}{ }^{\top}$ (synonym of DSM $4768^{\top}$ ), $\mathrm{T}^{\mathrm{T}} 228^{\top}$ (synonym of DSM $4766^{\top}$ ), AN6 ${ }^{\top}$ (synonym of DSM $3370^{\top}$ ) and $058^{\top}$ (synonym of DSM $4764^{\top}$ ). When known, the Steinernema species of the corresponding nematode host is indicated. Groups $G_{1}$ to $G_{13}$ are indicated. 
strains were characterized mainly by their ability to grow only at temperatures below $33{ }^{\circ} \mathrm{C}$ and their ability to assimilate D-gluconate (Table 2). Strain VN01 and $X$. japonica DSM $16522^{\mathrm{T}}$ (group $\mathrm{G}_{6}$ ) had very different phenotypic patterns (Fig. 3; Table 2) and therefore could not be considered to belong to the same species on the basis of our phenotypic and molecular analysis alone. Strains $\mathrm{KE}^{\mathrm{T}}{ }^{\mathrm{T}}$, KR01 and KR05 (X. hominickii, group $\mathrm{G}_{7}$ ) clustered together based on phenotypic patterns, confirming that these strains belonged to the same species. The phenotypic patterns of the $X$. poinarii strains isolated from $S$. glaseri clustered together and were distinguished from the phenotypic pattern of $X$. poinarii CU01 isolated from $S$. cubanum. The $X$. poinarii strains were characterized mainly by their ability to grow at $40^{\circ} \mathrm{C}$, an absence of DNase and lecithinase activities and an inability to assimilate putrescine (Table 2). Strains JM26 and USTX62 ${ }^{\mathrm{T}}$ (X. cabanillasii, group $G_{13}$ ) clustered together on the basis of phenotypic

Table 2. Main phenotypic characters of the previously described Xenorhabdus species and of the ten proposed novel Xenorhabdus species determined in this study

Taxa: 1, X. beddingii $\mathrm{Q}^{\mathrm{T}}{ }^{\mathrm{T}}$; 2, X. bovienii (24 strains studied); 3, unclassified strain TB20; 4, X. budapestensis (2 strains); 5 , X. ehlersii (5 strains); 6, 'X. indica' (2 strains); 7, X. innexi (2 strains); 8, X. japonica DSM 16522 ; 9, unclassified strain VN01; 10, X. nematophila (13 strains); 11, X. poinarii (5 strains); 12, X. szentirmaii (3 strains); 13, X. cabanillasii sp. nov. (2 strains); 14, X. doucetiae sp. nov. (2 strains); $15, X$. griffiniae sp. nov. ID10 ${ }^{\mathrm{T}}$; 16, X. hominickii sp. nov. (3 strains); 17, X. koppenhoeferi sp. nov. USNJ01 ; 18, X. kozodoii sp. nov. (3 strains); $19, X$. mauleonii sp. nov. $\mathrm{VC}^{\mathrm{T}}$; 20, X. miraniensis sp. nov. $\mathrm{Q} 1^{\mathrm{T}} ; 21, X$. romanii sp. nov. PR06- ${ }^{\mathrm{T}} ; 22, X$. stockiae sp. nov. TH01 ${ }^{\mathrm{T}}$. ,$+ 90 \%$ of strains positive; $\mathrm{V}(+), 50-89 \%$ of strains positive; $\mathrm{V}(-), 11-49 \%$ of strains positive;,$- 0-10 \%$ of strains positive; $\mathrm{V}$, variable; $\mathrm{W}$, weak.

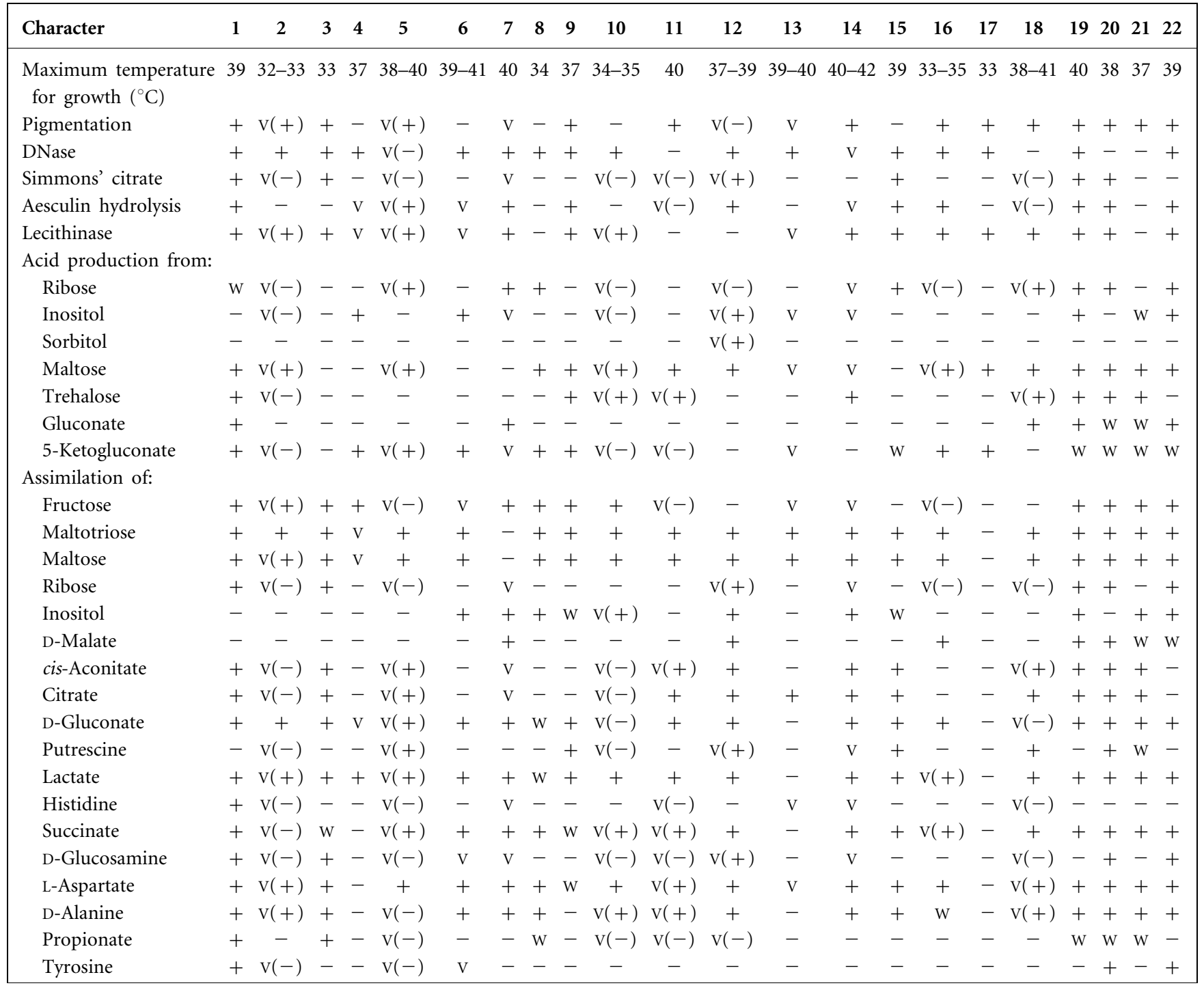




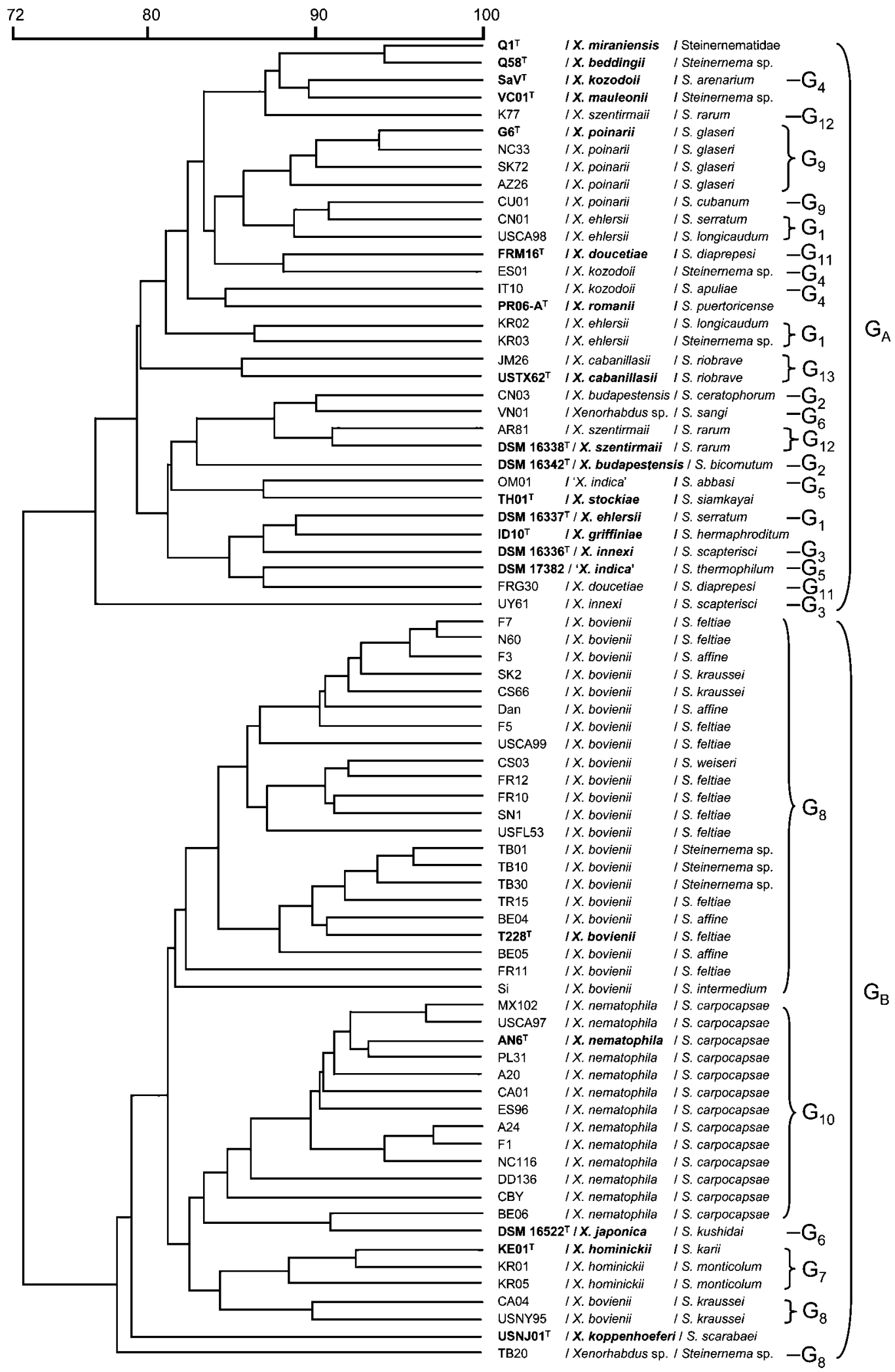

patterns, confirming that they belonged to the same species. Thus, at least for these strains, phenotypic analysis confirmed the high reliability of our molecular classification of the Xenorhabdus strains.
For groups $G_{4}$ and $G_{12}$, the phenotypic patterns of the corresponding strains were not grouped together in hierarchical analysis (Fig. 3). However, for group $\mathrm{G}_{4}$ (Xenorhabdus kozodoii sp. nov.), composed of three strains 
Fig. 3. Comparison of the phenotypic patterns of the 76 Xenorhabdus strains and isolates studied. Five similarity matrices were calculated on the basis of variable characters only, each corresponding to a set of data: growth at different temperatures, enzyme activities, carbon source assimilation and fermentation and phenotypic tests on agar plates. The phenotypic patterns were compared using the Gower similarity coefficient, making it possible to include weakly positive signals, recorded as 0.5 . The five similarity matrices were combined using BioNumerics software (Applied Maths) and the resulting dendrogram was calculated using UPGMA. Type strains are highlighted in bold. Phenotypic patterns were established for strains $\mathrm{G6}^{\top}$ (synonym of DSM $4768^{\top}$ ), T228 $^{\top}$ (synonym of DSM $4766^{\top}$ ), AN6 ${ }^{\top}$ (synonym of DSM $3370^{\top}$ ) and $058^{\top}$ (synonym of DSM $4764^{\top}$ ). When known, the Steinernema species of the corresponding nematode host is indicated. Groups $G_{1}$ to $G_{13}$ and phenotypic groups $G_{A}$ and $G_{B}$ are indicated.

originating from different countries (Italy, Russia, Spain), a combination of phenotypic features (proposed in the species description below) was found to distinguish these strains from the other Xenorhabdus strains studied (Table 2). Similarly, for group $\mathrm{G}_{12}$, composed of three strains, including the type strain X. szentirmaii DSM $16338^{\mathrm{T}}$, a combination of phenotypic features was used to distinguish these three strains unambiguously from the other Xenorhabdus strains studied [acid produced from sorbitol, assimilation of $\mathrm{D}(+)$-malate, no lecithinase activity and no assimilation of fructose]. Unlike strain DSM $16348^{\mathrm{T}}$, strains AR81 and K77 were able to assimilate ribose and to produce acid from fructose, mannose and inositol.

For each of groups $\mathrm{G}_{1}$ (X. ehlersii), $\mathrm{G}_{2}$ (X. budapestensis), $\mathrm{G}_{3}$ ( $X$. innexi), $\mathrm{G}_{5}$ (' $X$. indica') and $\mathrm{G}_{11}$ ( $X$. doucetiae), the phenotypic patterns of the corresponding strains were not grouped together (Fig. 3) and no phenotypic feature could be identified that distinguished these groups unambiguously from the other Xenorhabdus strains studied. However, the biochemical characteristics of the type strain X. ehlersii DSM $16337^{\mathrm{T}}$ defined by Lengyel et al. (2005) were shared by the four new isolates that we assigned to this species, with the exception of assimilation of fructose, arabinose, xylose, rhamnose, phenylacetate and tyrosine, displayed by none of the four isolates. Unlike the type strain X. budapestensis DSM $16342^{\mathrm{T}}$ (Lengyel et al., 2005), strain CN03 produced indole, hydrolysed aesculin, produced acid from acetylglucosamine and assimilated maltotriose, maltose, $\mathrm{N}$-acetyl-D-glucosamine, D-gluconate, L-glutamate, L-proline, L-alanine and $\mathrm{L}$-serine. The biochemical characteristics of the type strain $X$. innexi DSM $16336^{\mathrm{T}}$ (Lengyel et al., 2005) were shared by strain UY61, but UY61 was also able to assimilate Simmons' citrate and histidine, to produce indole and to ferment inositol. The biochemical characteristics of the proposed type strain ' $X$. indica' DSM 17382 (Somvanshi et al., 2006) were shared by strain OM01, but OM01 was also able to assimilate $\mathrm{N}$-acetyl-D-glucosamine and tyrosine and to hydrolyse aesculin. No combination of phenotypic traits was identified that distinguished strains $\mathrm{TH} 01^{\mathrm{T}}, \mathrm{ID} 10^{\mathrm{T}}, \mathrm{USNJ}^{\mathrm{T}} 1^{\mathrm{T}}, \mathrm{VCO}^{\mathrm{T}}$, $\mathrm{Q}^{\mathrm{T}}, \mathrm{PR} 06-\mathrm{A}^{\mathrm{T}}, X$. japonica DSM $16522^{\mathrm{T}}$ or X. beddingii DSM $4764^{\mathrm{T}}$ from the other Xenorhabdus species (Table 2).

\section{Description of Xenorhabdus cabanillasii sp. nov.}

Xenorhabdus cabanillasii [ca.ba.nil'la.si.i. N.L. gen. masc. n. cabanillasii in honour of H. E. Cabanillas, who described the nematode host of this bacterium, Steinernema riobrave (Cabanillas et al., 1994)].

The upper temperature limiting growth of the two known strains of this species in LB broth lies between 39 and $40{ }^{\circ} \mathrm{C}$. Assimilates Simmons' citrate, does not hydrolyse aesculin, does not ferment ribose, sorbitol, trehalose or gluconate and does not assimilate ribose, inositol, D-malate, cis-aconitate, D-gluconate, putrescine, lactate, succinate, D-glucosamine, propionate or tyrosine. Known strains are symbiotically associated with the entomopathogenic nematode Steinernema riobrave, from which two geographical ecotypes have been isolated, USTX $62^{\mathrm{T}}$ from Texas (USA) and JM26 from the Caribbean island of Jamaica.

The type strain is strain USTX62 ${ }^{\mathrm{T}}\left(=\mathrm{CIP} 109066^{\mathrm{T}}=\mathrm{DSM}\right.$ $\left.17905^{\mathrm{T}}\right)$. The GenBank accession number of the 16S rRNA gene sequence of the type strain is AY521244.

\section{Description of Xenorhabdus doucetiae sp. nov.}

Xenorhabdus doucetiae [dou.ce'ti.ae. N.L.gen. fem.n. doucetiae in honour of M. M. A. Doucet, who described the first Steinernema species from South America (Doucet, 1986)].

The upper temperature limiting growth of the two known strains of this species in LB broth lies between 40 and $42{ }^{\circ} \mathrm{C}$. Produces acid from trehalose and assimilates inositol, cis-aconitate and citrate. Known strains are symbiotically associated with the entomopathogenic nematode Steinernema diaprepesi (Nguyen \& Duncan, 2002), isolated in Central America and the Caribbean islands.

The type strain is strain FRM $16^{\mathrm{T}}\left(=\mathrm{CIP} 109074^{\mathrm{T}}=\mathrm{DSM}\right.$ $\left.17909^{\mathrm{T}}\right)$. The GenBank accession number of the 16S rRNA gene sequence of the type strain is DQ211709.

\section{Description of Xenorhabdus griffiniae sp. nov.}

Xenorhabdus griffiniae [grif.fi'ni.ae. N.L. gen. fem. n. griffiniae in honour of C. T. Griffin, who has contributed to the systematics of the nematode host, Steinernema hermaphroditum (Stock et al., 2004)].

The upper threshold limiting growth in LB broth is $39^{\circ} \mathrm{C}$. Colonies are not pigmented. Does not acidify inositol, sorbitol, maltose, trehalose or gluconate. Assimilates putrescine. The type strain is symbiotically associated with 
the entomopathogenic nematode Steinernema hermaphroditum, isolated in Indonesia.

The type strain is strain $\operatorname{ID} 10^{\mathrm{T}}\left(=\mathrm{CIP} 109073^{\mathrm{T}}=\mathrm{DSM}\right.$ $17911^{\mathrm{T}}$ ). The GenBank accession number of the 16S rRNA gene sequence of the type strain is DQ211710.

\section{Description of Xenorhabdus hominickii sp. nov.}

Xenorhabdus hominickii (ho.mi.ni' cki.i. N.L. gen. masc. n. hominickii in honour of W. M. Hominick, who has contributed to the systematics of entomopathogenic nematode-bacterium complexes).

The maximum temperature at which the three known strains of this species can grow is between 33 and $35^{\circ} \mathrm{C}$. Colonies are yellow. Produces indole, an exceptional characteristic in the genus Xenorhabdus, and hydrolyses aesculin. Produces acid from D-malate and 5-ketogluconate and does not assimilate Simmons' citrate, citrate, cis-aconitate, inositol or D-glucosamine. The isolates of this species are symbiotically associated with the entomopathogenic nematodes Steinernema karii (Waturu et al., 1997) and Steinernema monticolum (Stock et al., 1997), from Kenya and Korea, respectively.

The type strain is strain $\mathrm{KE} 01^{\mathrm{T}}\left(=\mathrm{CIP} 109072^{\mathrm{T}}=\mathrm{DSM}\right.$ $17903^{\mathrm{T}}$ ). The GenBank accession number of the 16S rRNA gene sequence of the type strain is DQ211719.

\section{Description of Xenorhabdus koppenhoeferi sp. nov.}

Xenorhabdus koppenhoeferi [kop.pen.hoe'fe.ri. N.L. gen. masc. n. koppenhoeferi in honour of A. Koppenhöfer, who has contributed to the systematics of the nematode host, Steinernema scarabaei (Stock \& Koppenhöfer, 2003)].

The upper temperature limiting growth in LB broth is $33^{\circ} \mathrm{C}$. Colonies are yellow. Produces acid from maltose and 5ketogluconate. The type strain is symbiotically associated with the entomopathogenic nematode Steinernema scar$a b a e i$, isolated from New Jersey (USA).

The type strain is strain USNJ01 ${ }^{\mathrm{T}}\left(=\mathrm{CIP} 109199^{\mathrm{T}}=\mathrm{DSM}\right.$ $\left.18168^{\mathrm{T}}\right)$. The GenBank accession number of the 16S rRNA gene sequence of the type strain is DQ205450.

\section{Description of Xenorhabdus kozodoii sp. nov.}

Xenorhabdus kozodoii [ko.zo'do.i.i. N.L. gen. masc. n. kozodoii in honour of E. M. Kozodoi, who described the nematode host Steinernema arenarium (Neoplectana anomali) (Kozodoi, 1984)].

The upper temperature limiting growth of the three known strains of this species in LB broth is between 38 and $41{ }^{\circ} \mathrm{C}$. Produces acid from gluconate and assimilates putrescine. Has no DNase activity and does not assimilate fructose. Does not produce acid from 5-ketogluconate. Known strains are symbiotically associated with the entomopathogenic nematodes Steinernema arenarium and Steinernema apuliae (Triggiani et al., 2004), isolated in Russia and Italy, respectively.

The type strain is strain $\mathrm{SaV}^{\mathrm{T}}\left(=\mathrm{CIP} 109068^{\mathrm{T}}=\mathrm{DSM}\right.$ $17907^{\mathrm{T}}$ ). The GenBank accession number of the $16 \mathrm{~S}$ rRNA gene sequence of the type strain is DQ211716.

\section{Description of Xenorhabdus mauleonii sp. nov.}

Xenorhabdus mauleonii (mau.le.o'ni.i. N.L. gen. masc. n. mauleonii in honour of $\mathrm{H}$. Mauléon, who has made a major contribution to studies of the ecology and biodiversity of entomopathogenic nematode-bacterium complexes in the Caribbean region).

The upper temperature limiting growth in $\mathrm{LB}$ broth is $40^{\circ} \mathrm{C}$. Colonies are yellow and assimilate Simmons' citrate and Dmalate. Does not assimilate D-glucosamine or tyrosine. The type strain is symbiotically associated with an as-yetunidentified species of Steinernema isolated from the Caribbean island of St. Vincent.

The type strain is strain $\mathrm{VCO}^{\mathrm{T}}\left(=\mathrm{CIP} 109075^{\mathrm{T}}=\mathrm{DSM}\right.$ $17908^{\mathrm{T}}$ ). The GenBank accession number of the $16 \mathrm{~S}$ rRNA gene sequence of the type strain is DQ211715.

\section{Description of Xenorhabdus miraniensis sp. nov.}

Xenorhabdus miraniensis (mi.ra.ni.en'sis. N.L. fem. adj. miraniensis from Mirani, a small town in Australia, the source of the nematode from which the type strain was isolated).

The upper temperature limiting growth in LB broth is $38^{\circ} \mathrm{C}$. Has no DNase activity and assimilates Simmons' citrate and many carbohydrates, including D-malate, lactate, D-glucosamine, L-aspartate and L-tyrosine. The type strain is symbiotically associated with an as-yet-undescribed nematode of the Steinernematidae (Akhurst \& Boemare, 1988) isolated at Mirani in Queensland (Australia) and has not yet been found elsewhere.

The type strain is strain $\mathrm{Q} 1^{\mathrm{T}}\left(=\mathrm{CIP} 109069^{\mathrm{T}}=\mathrm{DSM}\right.$ $17902^{\mathrm{T}}$ ). The GenBank accession number of the 16S rRNA gene sequence of the type strain is DQ211713.

\section{Description of Xenorhabdus romanii sp. nov.}

Xenorhabdus romanii [ro.ma'ni.i. N.L. gen. masc. n. romanii in honour of J. Román, who described the nematode host Steinernema puertoricense (Román \& Figueroa, 1994)].

The upper temperature limiting growth in $\mathrm{LB}$ broth is $37^{\circ} \mathrm{C}$. Colonies are yellow and display no DNase activity or aesculin hydrolysis. Does not assimilate histidine and assimilates D-malate inefficiently. The type strain is symbiotically associated with the entomopathogenic nematode Steinernema puertoricense, isolated in Puerto Rico. 
The type strain is strain PR06- $\mathrm{A}^{\mathrm{T}}\left(=\mathrm{CIP} 109070^{\mathrm{T}}=\mathrm{DSM}\right.$ $\left.17910^{\mathrm{T}}\right)$. The GenBank accession number of the $16 \mathrm{~S}$ rRNA gene sequence of the type strain is DQ211717.

\section{Description of Xenorhabdus stockiae sp. nov.}

Xenorhabdus stockiae [sto' cki.ae. N.L. gen. fem. n. stockiae in honour of S. P. Stock, a leading figure in the systematics of Steinernema and particularly of the nematode host of this bacterium, Steinernema siamkayai (Stock et al., 1998)].

The upper temperature limiting growth in $\mathrm{LB}$ broth is $39^{\circ} \mathrm{C}$. Colonies are pink. Assimilates D-glucosamine and tyrosine in particular, but does not produce acid from trehalose. The type strain is symbiotically associated with the entomopathogenic nematode Steinernema siamkayai, isolated in Thailand.

The type strain is strain $\mathrm{TH} 01^{\mathrm{T}}\left(=\mathrm{CIP} 109067^{\mathrm{T}}=\mathrm{DSM}\right.$ $17904^{\mathrm{T}}$ ). The GenBank accession number of the 16S rRNA gene sequence of the type strain is DQ202309.

\section{Acknowledgements}

We would like to thank all those listed in Table 1 for providing nematodes and/or Xenorhabdus strains.

\section{References}

Akhurst, R. J. (1980). Morphological and functional dimorphism in Xenorhabdus spp., bacteria symbiotically associated with the insect pathogenic nematodes Neoaplectana and Heterorhabditis. J Gen Microbiol 121, 303-309.

Akhurst, R. J. (1983). Taxonomic study of Xenorhabdus, a genus of bacteria symbiotically associated with insect pathogenic nematodes. Int J Syst Bacteriol 33, 38-45.

Akhurst, R. J. (1986). Xenorhabdus nematophilus subsp. beddingii (Enterobacteriaceae): a new subspecies of bacteria mutualistically associated with entomopathogenic nematodes. Int J Syst Bacteriol 36, 454-457.

Akhurst, R. J. \& Boemare, N. E. (1988). A numerical taxonomic study of the genus Xenorhabdus (Enterobacteriaceae) and proposed elevation of the subspecies of X. nematophilus to species. J Gen Microbiol 134, 1835-1845.

Akhurst, R. J. \& Boemare, N. E. (2005). Genus XL. Xenorhabdus Thomas and Poinar 1979, 354 ${ }^{\mathrm{AL}}$ emend. Thomas and Poinar 1983, 878. In Bergey's Manual of Systematic Bacteriology, 2nd edn, vol. 2, part B, pp. 831-838. Edited by D. J. Brenner, N. R. Krieg, J. T. Staley \& G. M. Garrity. New York: Springer.

Akhurst, R. J., Mourant, R. G., Baud, L. \& Boemare, N. E. (1996). Phenotypic and DNA relatedness between nematode symbionts and clinical strains of the genus Photorhabdus (Enterobacteriaceae). Int J Syst Bacteriol 46, 1034-1041.

Akhurst, R. J., Boemare, N. E., Janssen, P. H., Peel, M. M., Alfredson, D. A. \& Beard, C. E. (2004). Taxonomy of Australian clinical isolates of the genus Photorhabdus and proposal of Photorhabdus asymbiotica subsp. asymbiotica subsp. nov. and $P$. asymbiotica subsp. australis subsp. nov. Int J Syst Evol Microbiol 54, 1301-1310.

Boemare, N. E. \& Akhurst, R. J. (1988). Biochemical and physiological characterization of colony form variants in
Xenorhabdus spp. (Enterobacteriaceae). J Gen Microbiol 134, 751-761.

Boemare, N. E., Akhurst, R. J. \& Mourant, R. G. (1993). DNA relatedness between Xenorhabdus spp. (Enterobacteriaceae), symbiotic bacteria of entomopathogenic nematodes and a proposal to transfer Xenorhabdus luminescens to a new genus, Photorhabdus gen. nov. Int J Syst Bacteriol 43, 249-255.

Brunel, B., Givaudan, A., Lanois, A., Akhurst, R. J. \& Boemare, N. (1997). Fast and accurate identification of Xenorhabdus and Photorhabdus species by restriction analysis of PCR-amplified 16S rRNA genes. Appl Environ Microbiol 63, 574-580.

Cabanillas, H. E., Poinar, G. O., Jr \& Raulston, J. R. (1994). Steinernema riobravis sp. nov. (Rhabditida: Steinernematidae) from Texas. Fundam Appl Nematol 17, 123-131.

Doucet, M. M. A. (1986). A new species of Neoaplectana Steiner, 1929 (Nematoda: Steinernematidae) from Cordoba, Argentina. Rev Nematol 9, 317-323.

Dutky, S. R. \& Hough, W. S. (1955). Note on a parasitic nematode from codling moth larvae, Carpocapsa pomonella. Proc Entomol Soc Wash 57, 244.

Elawad, S., Ahmad, W. \& Reid, A. P. (1997). Steinernema abbasi sp. n. (Nematoda: Steinernematidae) from the Sultanate of Oman. Fundam Appl Nematol 20, 435-442.

Fischer-Le Saux, M., Mauléon, H., Constant, P., Brunel, B. \& Boemare, N. (1998). PCR-ribotyping of Xenorhabdus and Photorhabdus isolates from the Caribbean region in relation to the taxonomy and geographic distribution of their nematode hosts. Appl Environ Microbiol 64, 4246-4254.

Fischer-Le Saux, M., Arteaga-Hernández, E., Mráček, Z. \& Boemare, N. E. (1999a). The bacterial symbiont Xenorhabdus poinarii (Enterobacteriaceae) is harbored by two phylogenetic related host nematodes: the entomopathogenic species Steinernema cubanum and Steinernema glaseri (Nematoda: Steinernematidae). FEMS Microbiol Ecol 29, 149-157.

Fischer-Le Saux, M., Viallard, V., Brunel, B., Normand, P. \& Boemare, N. E. (1999b). Polyphasic classification of the genus Photorhabdus and proposal of new taxa: P. luminescens subsp. luminescens subsp. nov., P. luminescens subsp. akhurstii subsp. nov., $P$. luminescens subsp. laumondii subsp. nov., $P$. temperata sp. nov., $P$. temperata subsp. temperata subsp. nov. and P. asymbiotica sp. nov. Int J Syst Bacteriol 49, 1645-1656.

Gancheva, A., Pot, B., Vanhonacker, K., Hoste, B. \& Kersters, K. (1999). A polyphasic approach towards the identification of strains belonging to Lactobacillus acidophilus and related species. Syst Appl Microbiol 22, 573-585.

Gower, J. C. \& Legendre, P. (1986). Metric and Euclidean properties of dissimilarity coefficients. J Classif 3, 5-48.

Hulton, C. S. J., Higgins, C. F. \& Sharp, P. M. (1991). ERIC sequences: a novel family of repetitive elements in the genomes of Escherichia coli, Salmonella typhimurium and other enterobacteria. Mol Microbiol 5, 825-834.

Jukes, T. H. \& Cantor, C. R. (1969). Evolution of protein molecules. In Mammalian Protein Metabolism, vol. 3, pp. 21-132. Edited by $\mathrm{H}$. N. Munro. New York: Academic Press.

Kozodoi, E. M. (1984). A new entomophagous nematode Neoplectana anomali sp. n. (Rhabditida: Steinernematidae) and its biology. Zool Zh 63, 1605-1609.

Lengyel, K., Lang, E., Fodor, A., Szállás, E., Schumann, P. \& Stackebrandt, E. (2005). Description of four novel species of Xenorhabdus, family Enterobacteriaceae: Xenorhabdus budapestensis sp. nov., Xenorhabdus ehlersii sp. nov. Xenorhabdus innexi sp. nov., and Xenorhabdus szentirmaii sp. nov. Syst Appl Microbiol 28, 115-122. 
Lim, H., Lee, K. H., Hong, C.-H., Bahk, G.-J. \& Choi, W. S. (2005). Comparison of four molecular typing methods for the differentiation of Salmonella spp. Int J Food Microbiol 105, 411-418.

Mazurier, S., van de Giessen, A., Heuvelman, K. \& Wernars, K. (1992). RAPD analysis of Campylobacter isolates: DNA fingerprinting without the need to purify DNA. Lett Appl Microbiol 14, 260-262.

Moran, N. A., Munson, M. A., Baumann, P. \& Ishikawa, H. (1993). A molecular clock in endosymbiotic bacteria is calibrated using the insect hosts. Proc R Soc Lond B 253, 167-171.

Mráček, Z., Sturhan, D. \& Reid, A. (2003). Steinernema weiseri n. sp. (Rhabditida, Steinernematidae), a new entomopathogenic nematode from Europe. Syst Parasitol 56, 37-47.

Nguyen, K. B. \& Duncan, L. W. (2002). Steinernema diaprepesi n. sp. (Rhabditida: Steinernematidae), a parasite of the citrus weevil Diaprepes abbreviatus (L) (Coleoptera: Curculionidae). J Nematol 34, 159-170.

Nishimura, Y., Hagiwara, A., Suzuki, T. \& Yamanaka, S. (1994). Xenorhabdus japonicus sp. nov. associated with the nematode Steinernema kushidai. World J Microbiol Biotechnol 10, 207-210.

Ochman, H. \& Wilson, A. C. (1987). Evolution in bacteria: evidence for a universal substitution rate in cellular genomes. J Mol Evol 26, 74-86.

Poinar, G. O., Jr (1966). The presence of Achromobacter nematophilus in the infective stage of a Neoplectana sp. (Steinernematidae: Nematoda). Nematologica 12, 105-108.

Poinar, G. O., Jr (1993). Origins and phylogenetic relationships of the entomophilic rhabditids, Heterorhabditis and Steinernema. Fundam Appl Nematol 16, 333-338.

Poinar, G. O., Jr \& Thomas, G. M. (1965). A new bacterium, Achromobacter nematophilus sp. nov. (Achromobacteriaceae: Eubacteriales) associated with a nematode. Int Bull Bacteriol Nomencl Taxon 15, 249-252.

Qiu, L., Fang, Y., Zhou, Y., Pang, Y. \& Nguyen, K. B. (2004). Steinernema guangdongense sp. n. (Nematoda: Steinernematidae), a new entomopathogenic nematode from southern China with a note on S. serratum (nomen nudum). Zootaxa 704, 1-20.

Román, J. \& Figueroa, W. (1994). Steinernema puertoricensis n. sp. (Rhabditida: Steinernematidae), a new entomopathogenic nematode from Puerto Rico. J Agric Univ Puerto Rico 78, 167-175.

Saitou, N. \& Nei, M. (1987). The neighbor-joining method: a new method for reconstructing phylogenetic trees. Mol Biol Evol 4, 406-425.

Saunders, J. E. \& Webster, J. M. (1999). Temperature effects on Heterorhabditis megidis and Steinernema carpocapsae infectivity to Galleria mellonella. J Nematol 31, 299-304.

Sicard, M., Ferdy, J. B., Pagès, S., Le Brun, B., Godelle, B., Boemare, N. \& Moulia, C. (2004). When mutualists are pathogens: an experimental study of the symbioses between Steinernema (entomopathogenic nematodes) and Xenorhabdus (bacteria). J Evol Biol 17, 985-993.

Sokal, R. R. \& Michener, C. D. (1958). A statistical method for evaluating systematic relationships. Univ Kansas Sci Bull 22, $1409-1438$
Somvanshi, V. S., Lang, E., Ganguly, S., Swiderski, J., Saxena, A. K. \& Stackebrandt, E. (2006). A novel species of Xenorhabdus, family Enterobacteriaceae: Xenorhabdus indica sp. nov., symbiotically associated with entomopathogenic nematode Steinernema thermophilum Ganguly and Singh, 2000. Syst Appl Microbiol 29, 519-525.

Stackebrandt, E. \& Goebel, B. M. (1994). Taxonomic note: a place for DNA-DNA reassociation and $16 \mathrm{~S}$ rRNA sequence analysis in the present species definition in bacteriology. Int J Syst Bacteriol 44, 846-849.

Stock, S. P. \& Koppenhöfer, A. M. (2003). Steinernema scarabaei n. sp. (Rhabditida: Steinernematidae), a natural pathogen of scarab larvae (Coleoptera: Scarabaeidae) from New Jersey. Nematology 5, 191-204.

Stock, S. P., Choo, H. Y. \& Kaya, H. K. (1997). An entomopathogenic nematode, Steinernema monticolum sp. n. (Rhabditida: Steinernematidae) from Korea with a key to other species. Nematologica 43, 15-29.

Stock, S. P., Samsook, V. \& Reid, A. P. (1998). A new entomopathogenic nematode Steinernema siamkayai $\mathrm{sp} . \mathrm{n}$. (Rhabditida: Steinernemtidae) from Thailand. Syst Parasitol 41, 105-113.

Stock, S. P., Griffin, C. T. \& Chaenari, R. (2004). Morphological and molecular characterization of Steinernema hermaphroditum $\mathrm{n}$. $\mathrm{sp}$. (Nematoda: Steinernematidae), an entomopathogenic nematode from Indonesia, and its phylogenetic relationship with other closely related taxa. Nematology 6, 401-412.

Swofford, D. L. (2003). PAUP ${ }^{*}$ - Phylogenetic Analysis Using Parsimony ${ }^{\star}$ and other methods, version 4.0b10. Sunderland, MA: Sinauer Associates.

Tailliez, P., Tremblay, J., Ehrlich, S. D. \& Chopin, A. (1998). Molecular diversity and relationship within Lactococcus lactis, as revealed by randomly amplified polymorphic DNA (RAPD). Syst Appl Microbiol 21, 530-538.

Thomas, G. M. \& Poinar, G. O., Jr (1979). Xenorhabdus gen. nov., a genus of entomopathogenic nematophilic bacteria of the family Enterobacteriaceae. Int J Syst Bacteriol 29, 352-360.

Travassos, L. (1927). Sobre o genera Oxysomatium. Bol Biol Sao Paulo 5, 20-21 (in Portuguese).

Triggiani, O., Mráček, Z. \& Reid, A. (2004). Steinernema apuliae sp. n. (Rhabditida: Steinernematidae): a new entomopathogenic nematode from southern Italy. Zootaxa 460, 1-12.

Vandamme, P., Pot, B., Gillis, M., de Vos, P., Kersters, K. \& Swings, J. (1996). Polyphasic taxonomy, a consensus approach to bacterial systematics. Microbiol Rev 60, 407-438.

Versalovic, J., Koeuth, T. \& Lupski, J. R. (1991). Distribution of repetitive DNA sequences in eubacteria and application to fingerprinting of bacterial genomes. Nucleic Acids Res 19, 6823-6831.

Waturu, C. N., Hunt, D. J. \& Reid, A. P. (1997). Steinernema karii sp. n. (Nematoda: Steinernematidae), a new entomopathogenic nematode from Kenya. Int J Nematol 7, 68-75.

Williams, J. G. K., Kubelik, A. R., Livak, K. J., Rafalski, J. A. \& Tingey, S. V. (1990). DNA polymorphisms amplified by arbitrary primers are useful as genetic markers. Nucleic Acids Res 18, 6531-6535. 